\title{
June 1966
}

Vol. LXXX No. 6

\section{The Journal of}

\section{Laryngology and Otology}

\author{
EDITED BY \\ G. H. BATEMAN \\ ASSISTANT EEDITOR \\ LIONEL TAYLOR
}

\section{Contents}

'Lateral TransthyroId ARYTEnoIdectomy : TOXOPLAsMosis iN GHIDHOOD

AABERRANT SALIVARY TUMOURS (REPORT OF FOUR Cases)

AMYlotDOSIS OF FroNTAI SINES

O. ChandRa, R. D. Melgtri

The Temporary Efrects of 125 C.P.S. Octave-Band NOISE ON STAPEDECTOMIZED EARS . . .

NeARING Aids

$\sqrt{\text { Aleukamic Leukama with Presenting Lesions }}$ Resembling MaLtgnave Granutoma

\section{Clintcal Records-}

SURGICAI. TREATMEnt OF OzENA WITH DERMOFAT GraFt

Familtal Benl's Palsy (CASE Report) K I Save
J. ATKINS

A. W. MORrison and J.S. R. Baxier

L. H. Hiranandani, nd N. L. Hiranandani BETSY BROWN

K. FERRIS JOHN C. RICE

LeWIS LABIB SAMY and FatMa H. ABDIN

ISKANDER H. GIRGIS PREM. K. KAKAR, $Y$ and P. S. SAHARIA T. R. BULE ABRAHAM BERKSTEIN HuSSEIN KaMEL ISMAIL Krnneth G. Malcomson R. SCOTt Stevenson

GENERAL Notes

\section{London \\ - Headley Brothers I 99 Kingsway $\mathrm{WC}_{2}$}




\title{
The Journal of \\ Laryngology and Otology
}

(FOUNDED in 1887 by MOREI.L MACkENZIB and NORRIS WOLFENDHN)

\author{
EDITED BY \\ G. H. BATEMAN \\ ASSISTANT EDITOR \\ LIONEL TAYLOR
}

1. Original articles which have not been published elsewhere are invited and should be sent to the Editor. They are considered for publication on the understanding that they are contributed to this Journal solely. Reproduction elsewhere, in whole or in part, is not permitted without the previous written consent of the Author and Editor and the customary acknowledgment must be made.

2. Manuscripts should be typewritten, on one side only of the paper, and well spaced. Captions to illustrations should be typed on a separate sheet and sent at the same time as original photographs, etc.

The Harvard system of recording references should be used, e.g. Grers, C., and Brown, D. (I95I) J. Larying., 65, 33. Abbreviations of Journals should follow the style recommended in World Medical Periodicals, published by World Health Organization, 1952.

It is most important that authors should verify personally the accuracy of every reference before submitting a paper for publication.

3. Galley proofs and engraver's proofs of illustrations are sent to the author. Corrections, which should be kept to a minimum, must be clearly marked, and no extra matter added. Proofs should be returned within 5 days.

4. Illustration blocks will normally be held by the Printers for three years, after which they will be destroyed. Any author is entitled to have these returned to him, but a request for this must be sent within three years of the appearance of the article, to Headiey Brothers, rog Kingsway, London, WC2. Coloured illustrations will be charged to authors, unless a special grant is authorized by the Editor.

5. Otders for reprints must be sent when returning galley proofs, and for this purpose special forms are supplied.

6. Authors of original communications on Oto-Laryngology in other journals are invited to send a copy, or two reprints, to the Journal of Laryngalogy. If they are willing, at the same time, to submit their own abstmct (in English, French, Iralian, or German) it will be welcomed.

7. Editorial communications may be addressed to THE EDiroR, Jound of Larytgalogy, c/o HzADLEY Brotrers, rog Kingsway, London, WC2.

8. The annual subscription is five guineas sterling (U.S.A. \$rs) post free, and payable in advance.

9. Single copies will be on sale at 128 . $6 \mathrm{~d}$, each; copies of parts up to Vol. LXIII which are available may be purchased at 78 . 6d. each.

ro. All subscriptions, advertising and business communications should be sent to the publishers, Hradiey Brothers, rog Kngsway, LONDON, WC2.

\section{United States of America}

Orders for this Journal may be sent through local booksellers, or to Stecheirt-HAmNer, INC., $31-33$ East 10 th Street, New York, or direct to the publishers, Headzey Brothers, rog Krngsway, London, WC2, England.

- Journal of Laryngology and Otology, 1966 


\section{ONTENTS}

Lateral Transthyroid Arytenoidectomy. J. Atkins (Birmingham) • 557

Toxoplasmosis in Childhood. A. W. Morrison and J.S. R. Baxter (London) 560

aberrant Salivary tumours (Report of Four Cases). L. $H$. Hiranandani, O. Chandra, R. D. Melgiri and N. L. Hiranandani 564

Amyloidosis of Frontal Sinus. Betsy Brown (Manchester) • $\quad 57 \mathrm{I}$

The Temporary Effects of i25 c.p.s. Octave-Band Noise on Stapedectomized EARS. K. Ferris (London) . . . . . 579

Hearing Aids. John C. Rice (London) . . . . . $\quad .583$

Aleuk amic Leuk emia with Presenting Lesions Resembling Malignant Granuloma. Lewis Labib Samy and Fatma H. Abdin (Cairo) . . . . . . . . . 60I

\section{Clinical Records-}

Surgical Treatment of Ozena with Dermofat Graft. Iskander H. Girgis . . . . . . . . . . $6 \mathrm{I}_{5}$

Familial Bell's Palsy (Case Report). Prem. K. Kakar, K. L. Sawhey and P. S. Saharia (New Delhi, India) . . . 628

Noise Trauma Deafness after Stapedectomy with Recovery. T. R. Bull (London) . . . . . . . . 631

The Treatment of Atrophic Rhinitis with Injectable Silicone. Abraham Berkstein (Mexico) . . . . . . . $\quad .634$

Gumma of the Vocal Cord (Clinical Report). Hussein Kamel Ismail . . . . . . . . . . 638

Wegener's Giant Cell Granulomatosis Treated with Corticosteroids. Kenneth G. Malcomson . . . . . $64^{\circ}$

Epistaxis and Tuberculosis. R. Scott Stevenson (Gibraltar) • 646

General Notes $\quad . \quad . \quad . \quad . \quad . \quad . \quad . \quad . \quad . \quad . \quad .648$ 


\section{ONLY AMPLIVOX provides a complete audiometric service!}

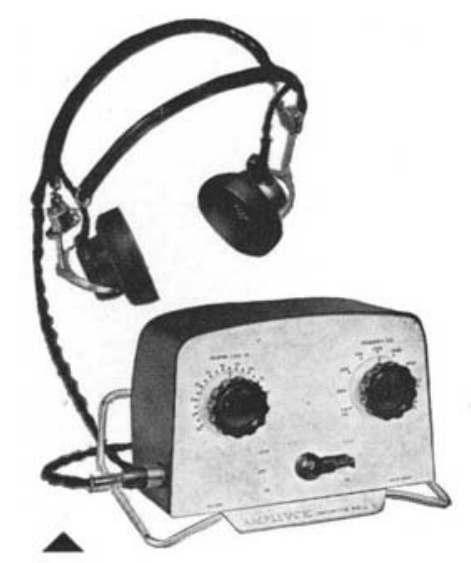

Transistor Audiometers

with air conduction or air and bone conduction with masking, for hospitals, schools, consulting rooms, industrial medical departments, screening programmes, etc.

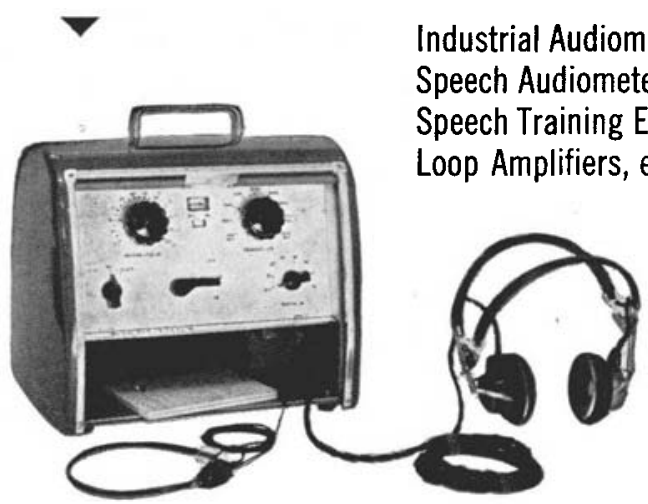

PLUS An efficient and speedy calibration service

please write for technical Iiterature to meet your needs

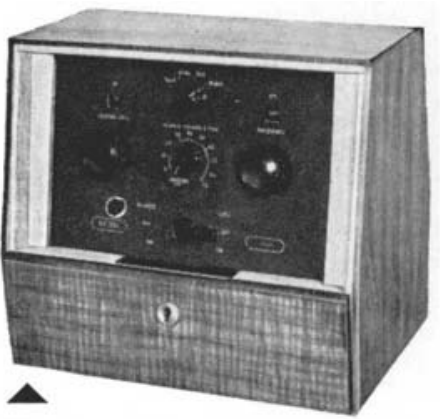

Clinical Audiometers

with narrow band masking for the highest accuracy and extended resolution.

\section{Audiometer Booths}

for ideal testing conditions in hospitals, clinics, factories. Standard and special sizes available.

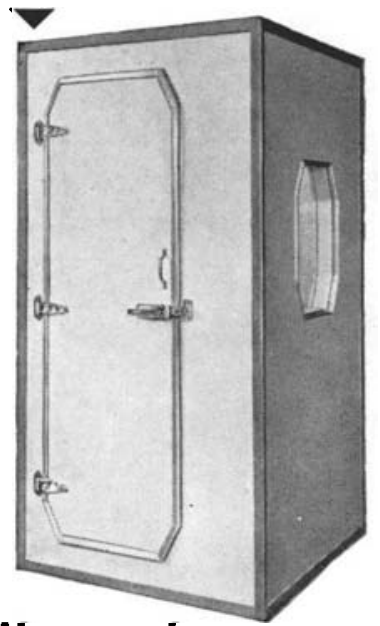

AMPLIVOX

HEARING ADVISORY SERVICE LTD.

80 New Bond Street, London, W.1. Tel: HYDe Park 9888

Please mention The Journal of Laryngology and Otology when replying to advertisements 


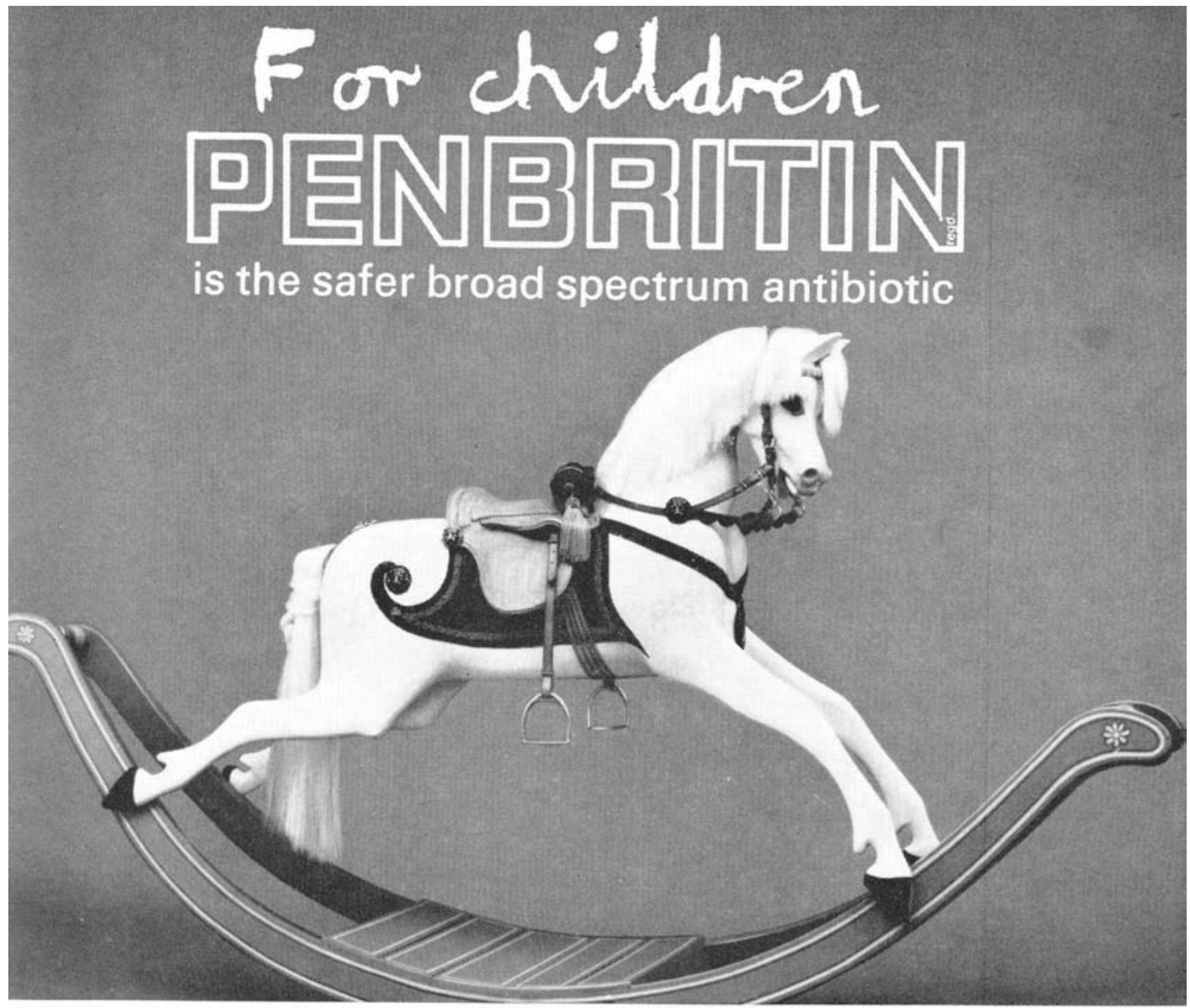

-the only one which is both oral and bactericidal, with the additional advantage of safety for all ages. Whenever broad spectrum therapy is required, from the neonate to the older child, Penbritin affords the safety of a penicillin.

No interference with the calcification of teeth and bone, or significant change in blood picture has been reported in over 700 published papers on Penbritin.

\section{Penbritin is effective}

because it is bactericidal, highly active against a wide range of pathogens and well absorbed after oral administration giving high blood, tissue and urine levels. These factors mean outstanding effectiveness in the treatment of recurrent chest infections, bronchitis, pneumonia, tonsillitis, otitis media, cystitis, pyelonephritis and other bacterial diseases.

\section{And acceptable}

because Penbritin Syrups are palatable, pleasant tasting liquids, well liked and well tolerated by children of all ages.

Crushable paediatric tablets are also available.

\section{Dosage}

Under 2 years $62.5-125 \mathrm{mg} .6$ hourly. 2-10 years $125-250 \mathrm{mg} .6$ hourly

Availability (for paediatric use)

只

Penbritin Syrup

$(125 \mathrm{mg} . / 5 \mathrm{ml}) .60 \mathrm{ml}$.

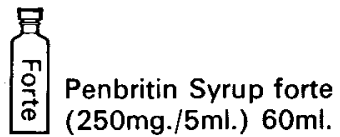




\section{BÉKESY ACCESSORY}

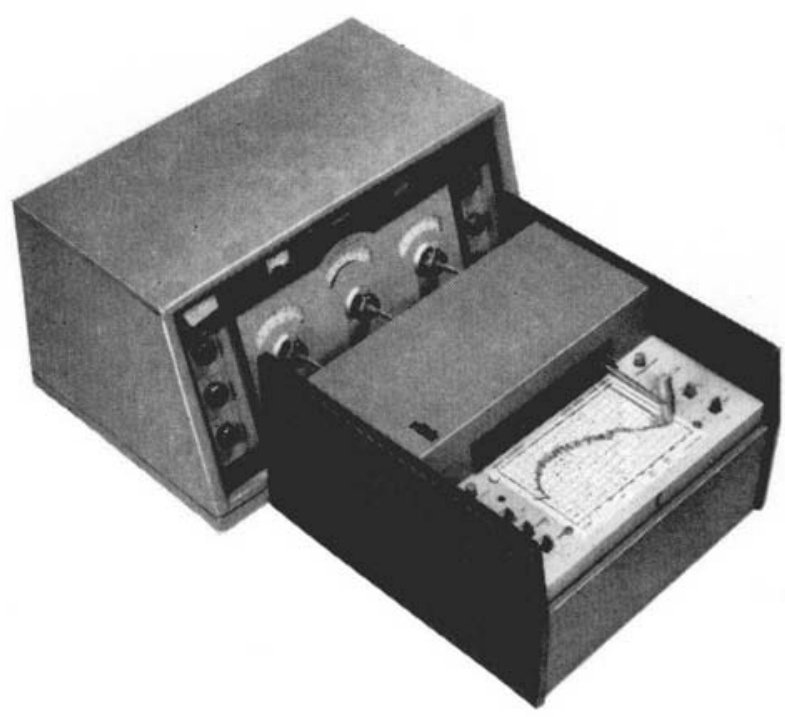

For the very first time a fully automatic unit has been made available for a Clinic Audiometer, making the combined units into a true BÉKÉSY Audiometer.

This automatic accessory is being made for the PETERS SPD/5 CLINIC AUDIOMETER, which has a continuous frequency range and continuously variable attenuation. The result is therefore a true Békésy audiometer.

It can be attached to or detached from the audiometer in under one minute so that the two units together offer the facilities of an advanced clinic audiometer or Békésy audiometry at will.

It can be fitted to any existing SPD/5 Audiometer.

Please write for full details and demonstration to:

\section{ALFRED PETERS \& SONS LIMITED}

\section{GELL STREET, SHEFFIELD 3}




\section{ORBDNIN and its sucgess in Gram-Positive Iniegtions}

\section{Otitis media Otitis externa}

Boils

Carbuncles

Infected dermatoses

Pneumonia

Lung abscess

Acute bronchitis

Osteomyelitis

Osteitis
Tonsillitis

Pharyngitis

Post-operative wound infections

Burns

Skin graft protection

Septicaemia

Acute endocarditis

Staphylococcal enterocolitis

Staphylococcal urinary tract infections

Staphylococcal meningitis
ORBENIN (cloxacillin sodium B.P.) is a penicillin active against virtually all Gram-positive organisms, including staphylococci, $\beta$-haemolytic streptococci and pneumococci, irrespective of their resistance to other antibiotics.

It is encouraging that the widespread use of Orbenin in hospitals has not resulted in the emergence of resistant strains.

More than 300 references in the World Literature testify to the excellent clinical results obtained with Orbenin in a wide variety of Gram-positive infections.

Detailed literature is available on request.
Dosage:

Two capsules (500mg.) or one vial (250mg.) q.i.d.

Availability:
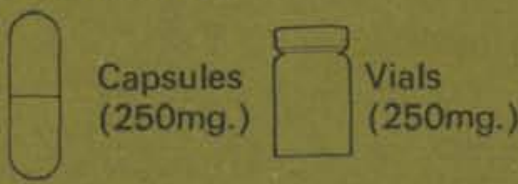
Syrup (125mg. $5 \mathrm{~mL}$ ) 


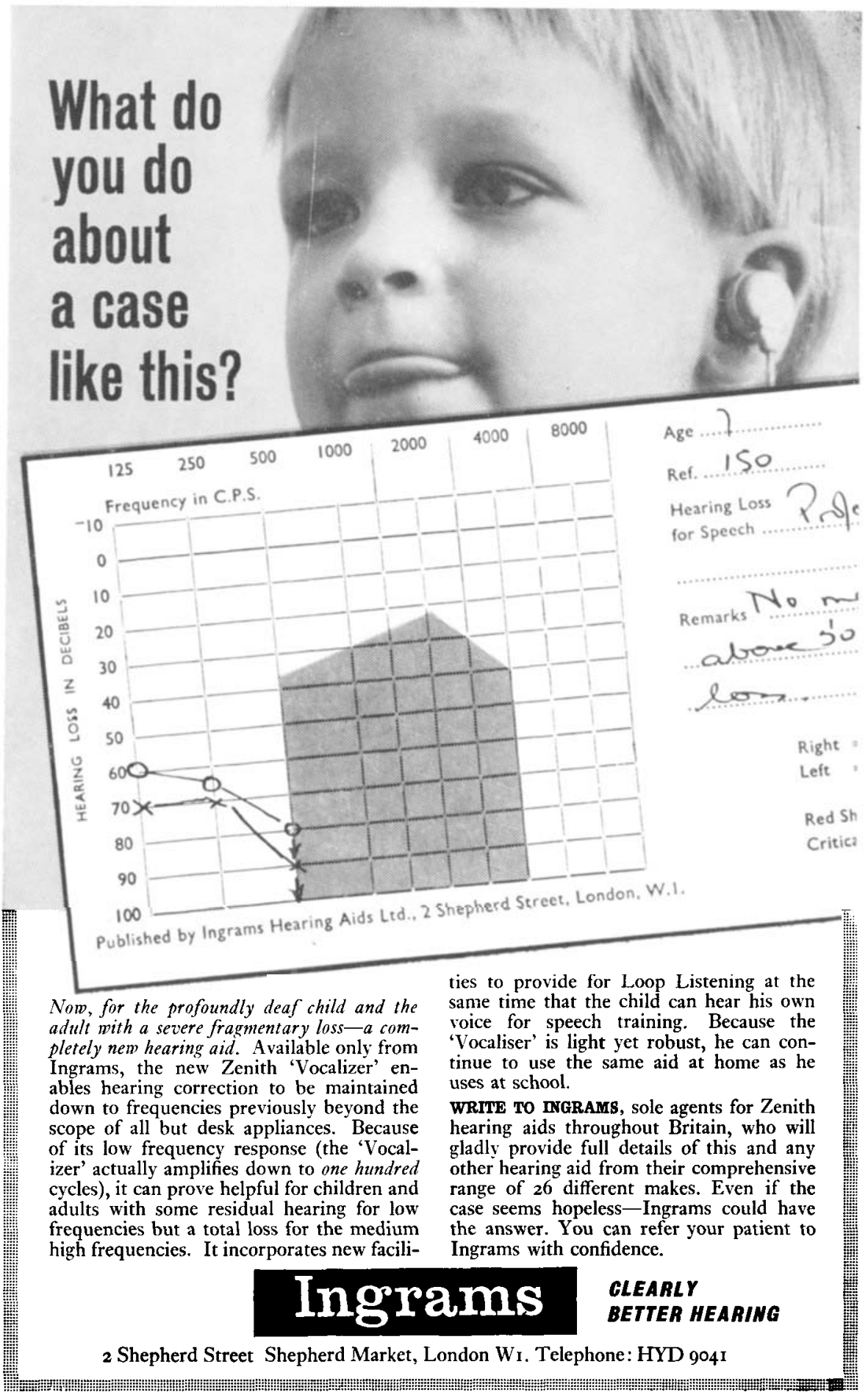

Please mention The Journal of Laryngology and Otology when replying to advertisements 
when everything in the garden's -

\section{deadly!}
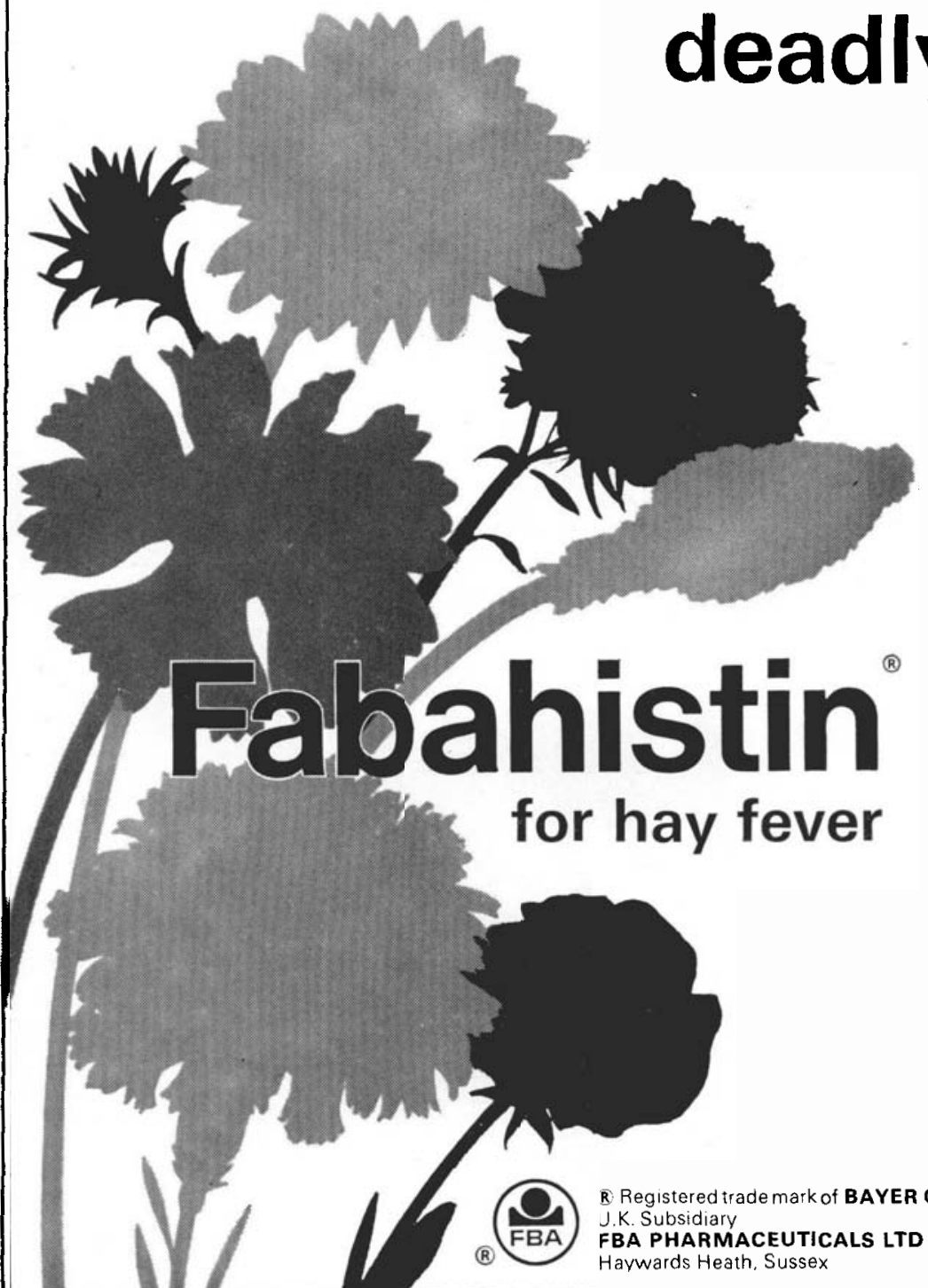

(R) Registered trade mark of BAYER GERMANY U.K. Subsidiary

FBA PHARMACEUTICALS LTD

Haywards Heath. Sussex 


\title{
THE LARYNGOSCOPE
}

\author{
A Monthly Journal \\ devoted to the disease of \\ EAR, NOSE AND THROAT
}

Official organ for the American Laryngological

Rhinological and Otological Society

Price $\$ 18.00$ per year

Foreign $\$ 19.00$ per year

ESTABLISHED 1896

\section{SOUTH EUCLID AVENUE SAINT LOUIS MO. 63110.}

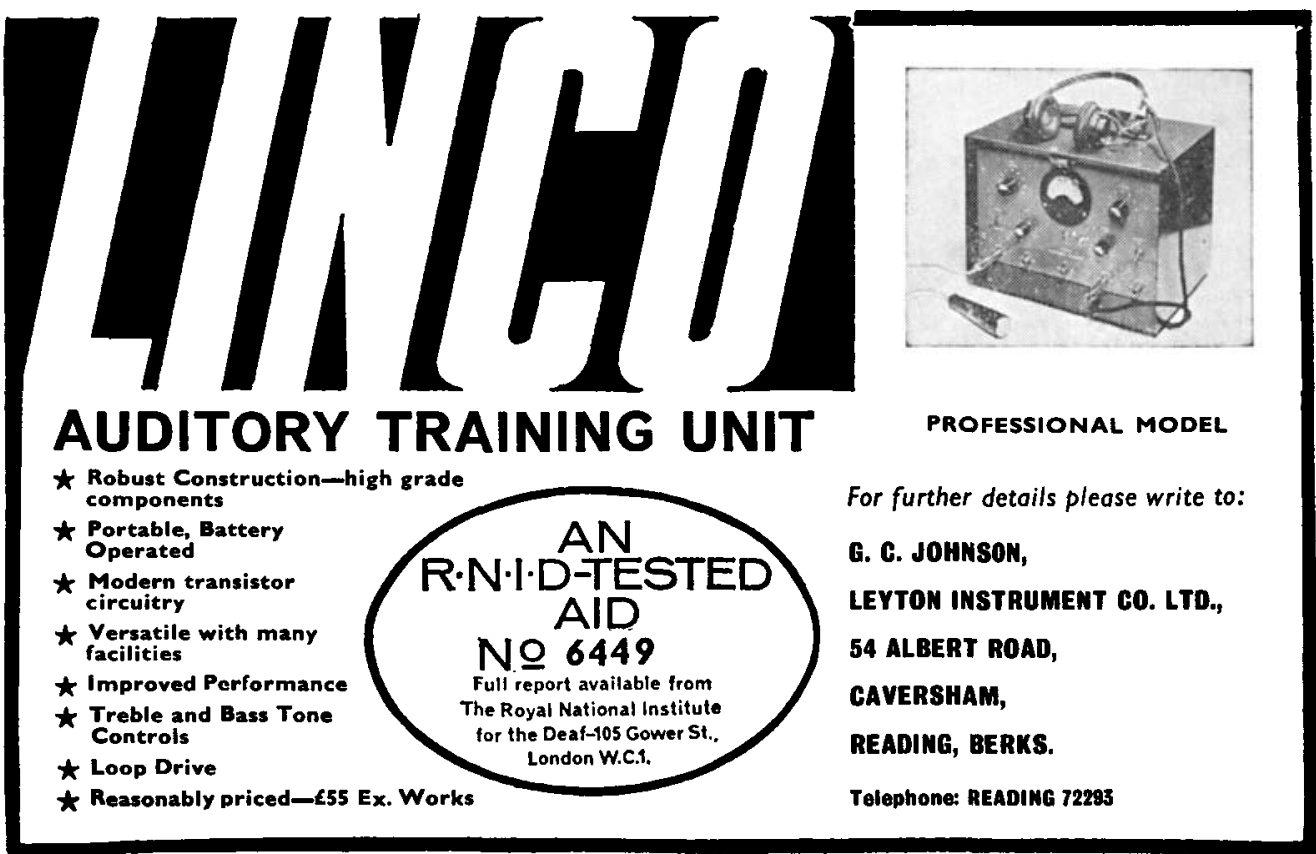

Please mention The Journal of Laryngology and Otology when replying to advertisements 


\section{In hay fever and 1 other pollinoses}

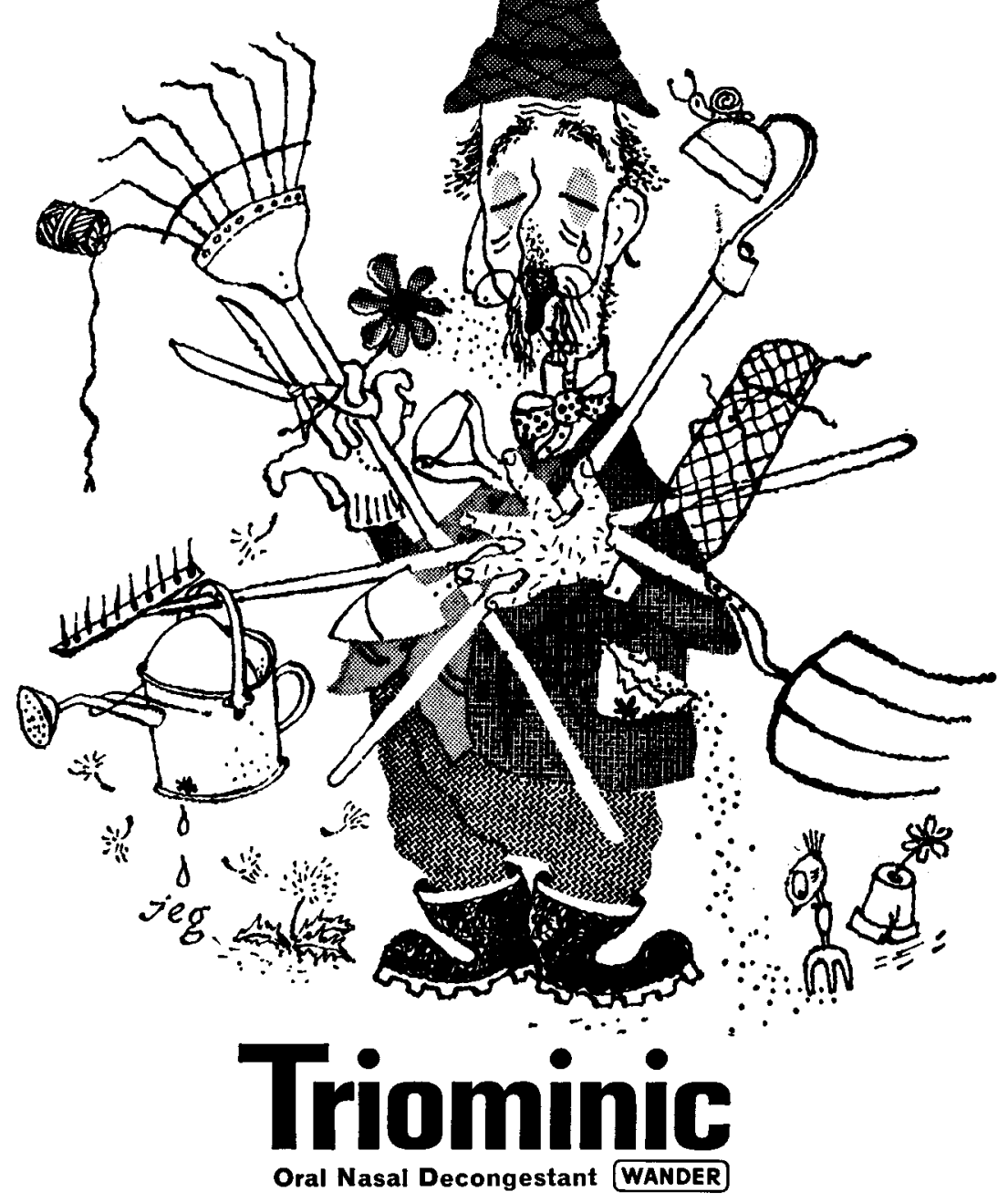

'Triominic' timed-release tablets and orangeflavoured syrup contain antihistamines and a decongestant in balanced proportions to ensure relief from symptoms of nasal allergy for between 6 and 8 hours. The active constituents of 'Triominic' -the original oral decongestant-reach the nasal mucosa systemically. This obviates the rebound congestion which may follow the topical use of vasoconstrictors.

Formula per timed-release tablet.

Phenylpropanolamine hydrochloride.....50 mg. Mepyramine maleate B.P..............25 mg.

Pheniramine maleate.................25 mg S7

'Triominic' is also available as an orange-flavoured syrup. Basic N.H.S. prices: 50 tablets $5 / 9 \frac{1}{2}$ 4 fl. oz. 2/2 (ex dispensing packs).

Literature and sample on request

M439A A. WANDER LIMITED - 42 UPPER GROSVENOR STREET - LONDON W.1.

Please mention $T$ be Journal of Laryngology and Otology when replying to advertisements 


\section{KAMPLEX}

AUDIOMETRIC EQUIPMENT

\section{AUDIOMETERS}

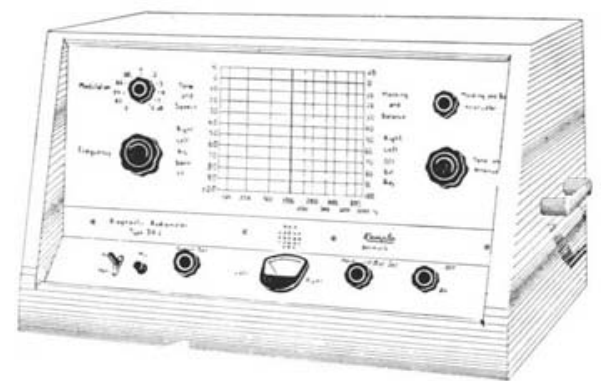

SCREENING PORTABLE TA16

DIAGNOSTIC PORTABLE TA15

CLINIC AUDIOMETER DA1

DOUBLE CHANNEL DA2

AUTOMATIC AUDIOMETER

CLINIC AUDIOMETER DA1

ACOUSTIC IMPEDANCE

APPARATUS ZA2

PNEUMOMETER ZP1

SKIN RESISTANCE

APPARATUS RA4

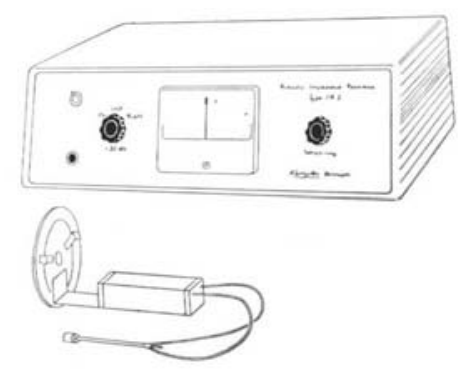

SOUND LEVEL METER GA6

VISIBLE SPEECH APPARATUS

AUDITORY TRAINERS

Write for full catalogue and detailed descriptions to:

\section{ALFRED PETERS \& SONS LTD}

51 GELL STREET, SHEFFIELD 3

Please mention 7 be Journal of Laryngology and $O$ tology when replying to advertisements 


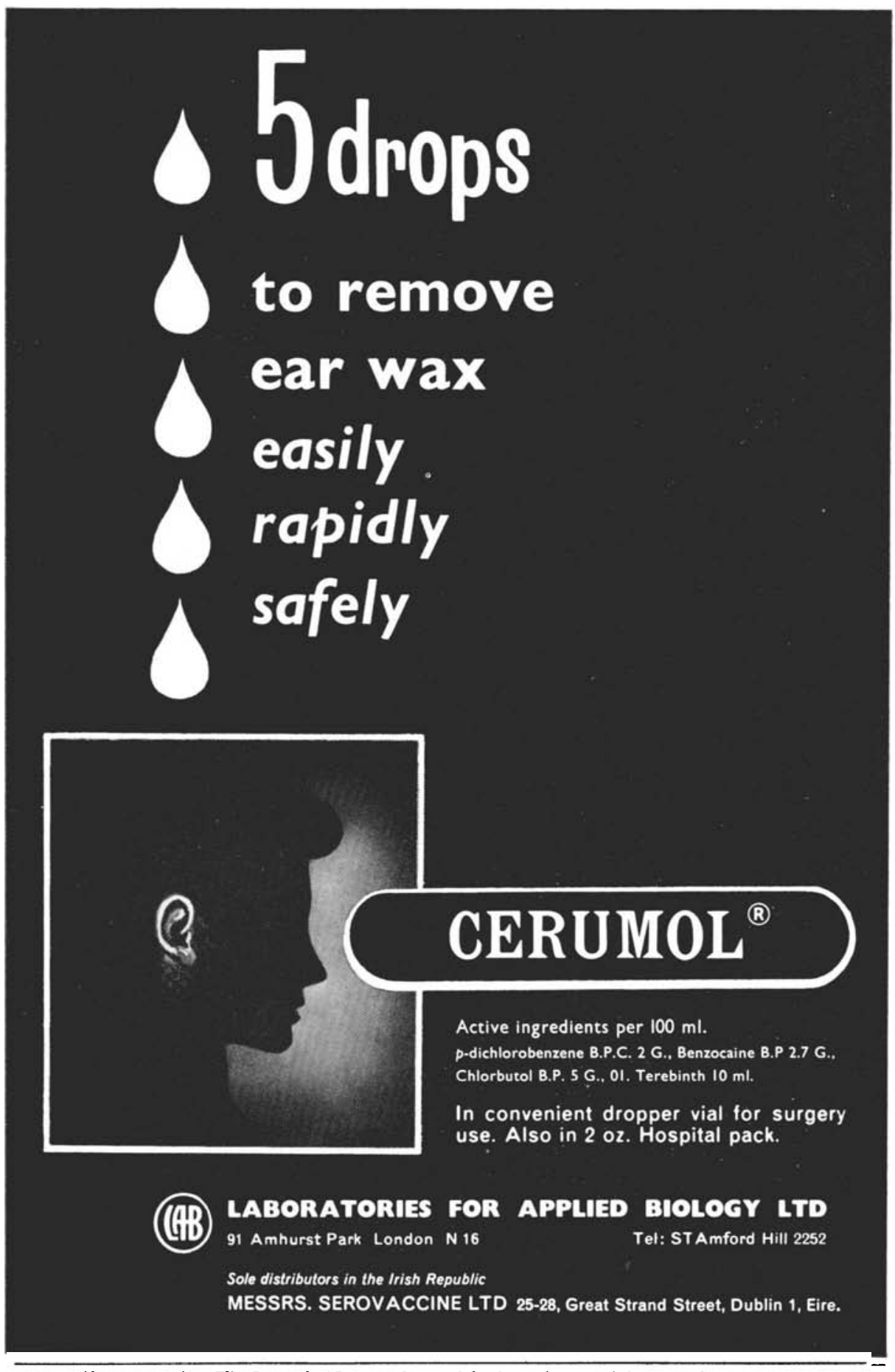

Please mention The Journal of Laryngology and Otology when replying to advertisements 


\section{For the longest- lasting, gentlest relief of HAY-FEVER}

A combination of a long-acting yet gentle decongestant with a topicallyeffective antihistamine. to provide prompt and sustained relief in all seasonal and perennial nasal allergies. One application at bedtime will usually maintain clear nasal airways until the morning. Nasal Spray or Drops: $\frac{1}{2} \mathrm{fl}$. oz. Basic NHS price $3 s .8 \mathrm{~d}$.

\section{Otrivine-Antistin}

xylometazoline tiydrochloride $0.05 \%$ antazoline sutphate $05 \%$

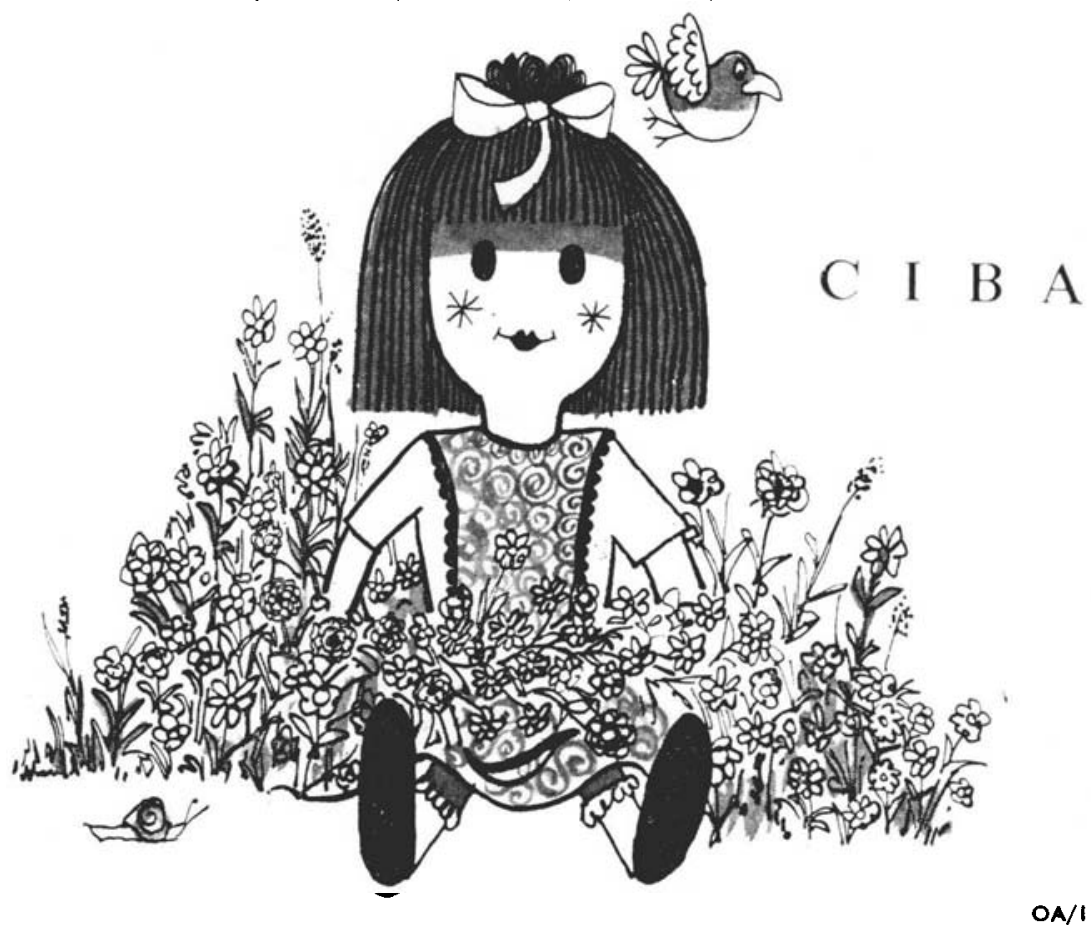

Please mention The Journal of Laryngology and Otology when replying to advertisements 
Now available to your patients on a minimum of I4 DAYS FREE TRIAL - WITHOUT CHARGE WITHOUT DEPOSIT - WITHOUT OBLIGATION

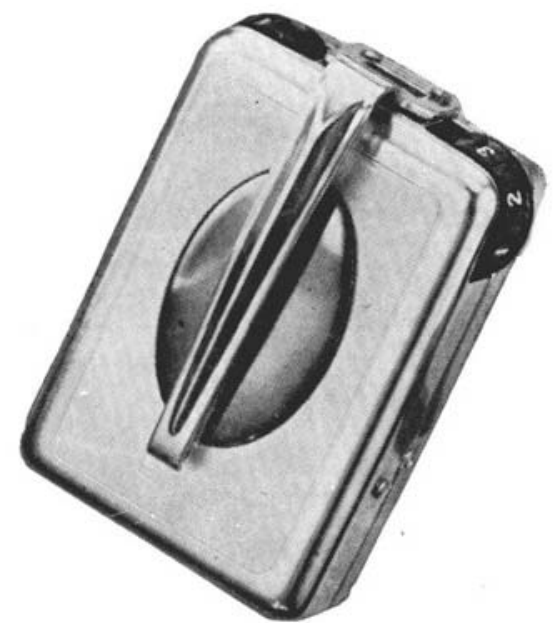

Price $\AA^{15} 15 s$.

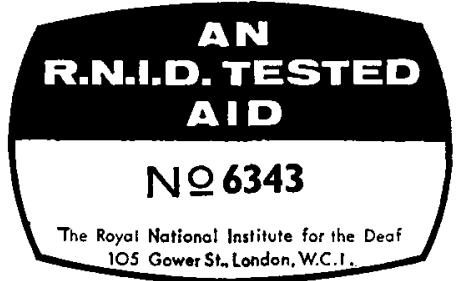

THE APOLLO TH 300

A very small inexpensive 4 transistor body worn aid with a high degree of amplification and maximum loudness (greater than the Medresco OL 56). The aid has a 3 position tone control and inductive pick-up coil for use with the telephone. Fully guaranteed and insured against "all risks" for 12 months. 24 hr. (return of post) repair service.

\section{THE CORTICON TH 701}

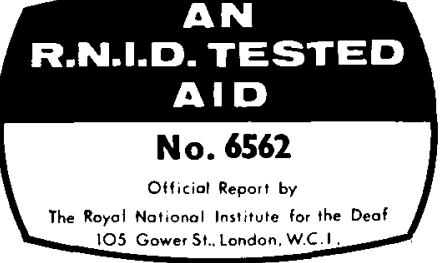

A well made inexpensive 4 transistor head worn aid with sufficient amplification and maximum loudness for hearing losses which are not severe. Fully guaranteed and insured against "all risks" for 12 months. 24 hr. (return of post) repair service.

The above aids are simple to operate and easy to fit.

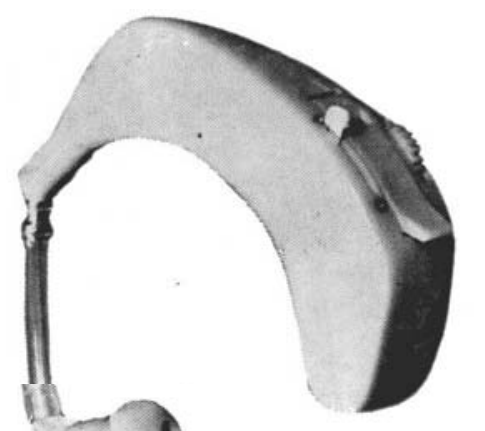

Price $f^{24}$ Ios.

It is our sincere belief that applicants should be given the opportunity to test an aid of their choice, in their own familiar surroundings, without pressure or persuasion. We therefore give our firm undertaking that no representative or salesman will call on any of your patients who request further details.

More information and copies of the R.N.I.D. Test Report from:

Mr. Monty Shulberg, CUBEX LIMITED, 57 Southover, Woodside Park, London, N.I2. Telephone HILlside 7625 .

Please mention The Journal of Laryngology and Otology when replying to advertisements 


\section{WHEN A HEARING AID IS RECOMMENDED ONLY AMPLIVOX OFFERS THIS HEARING AID SERVICE}

The design and manufacture of a complete range with individual fitting facilities.

Best of other makes in addition to Amplivox aids-Amplivox hearing aids are ONLY available from Amplivox.

Highest degree of training of any hearing aid organisation.

Master Hearing Aid evaluations.

Expert follow-up and rehabilitation advice.

15 branch offices with while-you-wait service.

FOR YOUR PATIENTS' GREATEST SATISFACTION SPECIFY AMPLIVOX

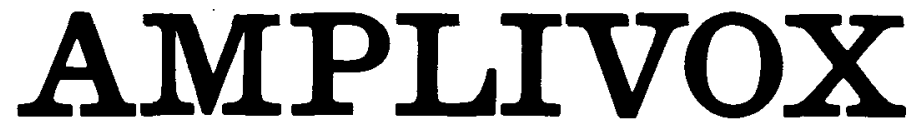

World's most experienced and complete hearing service

\section{AMPLIVOX HEARING ADVISORY SERVICE \\ 80 NEW BOND STREET \\ LONDON, W.1}




\section{In cases of PERCEPTIVE DEAFNESS} whenever a Hearing Aid is indicated let your patients test the MULTTTONE PERCEPTOR

A New small Post-Aural Aid of British design and manufacture. The unique Multitone method of mounting the microphone at the top of the unit in an acoustic chamber facing forward produces direct FRONTAL RECEPTION of astonishingly wide frequency response.

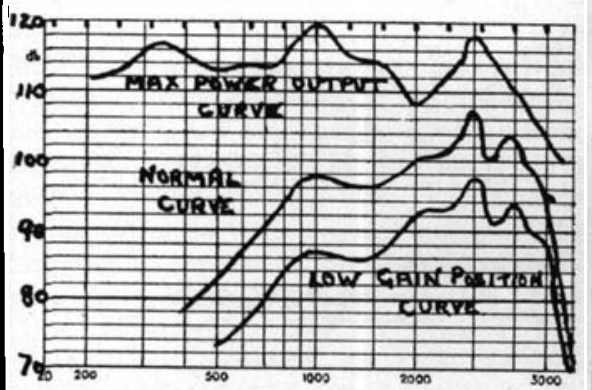

Frequency Response 500 - 5000 cps. Maximum Amplification (at $3000 \mathrm{cps}$ ) $46 \mathrm{~dB}$. Maximum power output $(1000 \mathrm{cps}) 120 \mathrm{~dB}$.

Arrangements can be made for your patients to test the Perceptor without charge or obligation. For information please contact

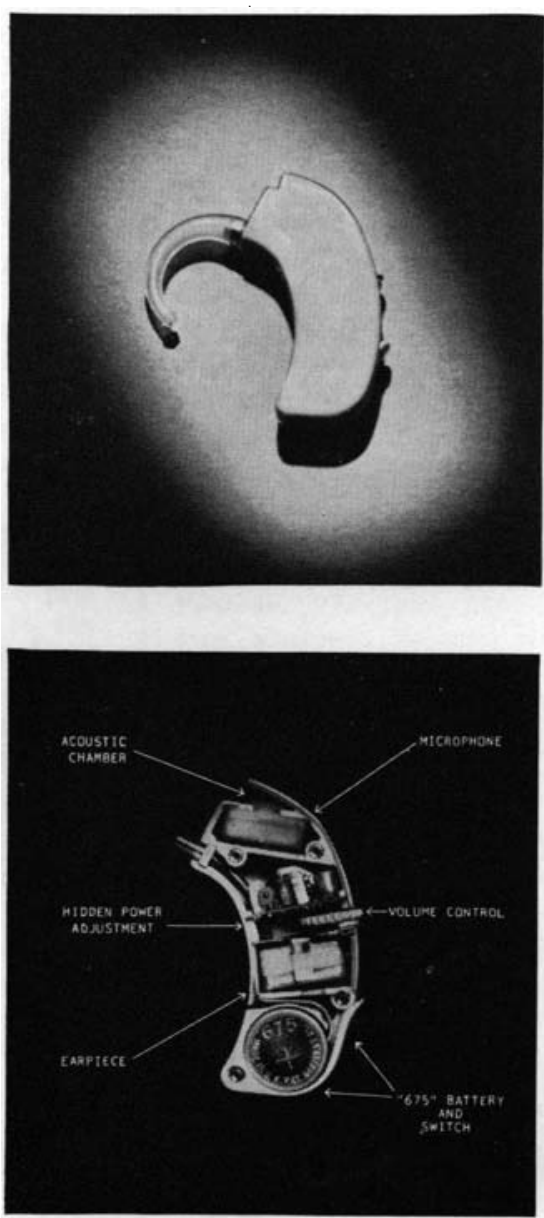

MULTITONE ELECTRIC CO LTD - 12-20 UNDERWOOD STREET LONDON N1 - TELEPHONE: CLERKENWELL 8022 
For Advertisement

Space in this Journal

please apply to:

\section{The Journal of Laryngology and Otology \\ 109 Kingsway \\ London W.C.1}

Please mention The Journal of Laryngology and Otology when replying to advertisements 


\section{A CHOICE SELECTION IN LARYNGOLOGY \& OTOLOGY}

\begin{abstract}
ALARYNGEAL SPEECH by William M. Diedrich and Karl A. Youngstrom, both of University of Kansas Medical Center, Kansas City. The authors report on an extensive research study and describe in detail clinical observations and rehabilitation procedures. The unique illustrative material presented facilitates a visual understanding of the complex processes of alaryngeal speech. Physical and psychological needs as well as communication needs of the laryngectomee are considered. A new concept for developing csophageal speech through the use of the artificial larynx is presented. June ' 66 , about $282 \mathrm{pp}$., 322 il., 51 tables.
\end{abstract}

ROENTGENOGRAPHY AND ROENTGENOLOGY OF THE MIDDLE EAR AND MASTOID PROGESS by Lewis E. Etter, Univ. of Pittsburgh. With the collaboration of Lawrence C. Cross and Merle J. Stuart, both of Western Psychiatric Institute and Clinic. All of Pittsburgh. The author demonstrates how a routine acceptable x-ray examination of the temporal bone, middle ear, and mastoid process can be performed using six pairs of films, properly exposed by precision roentgenography, to show all that is needed to arrive at a diagnosis of disease in these structures. ' $65,168 \mathrm{pp} .\left(8 \frac{1}{2} \times_{I I}\right), I_{57} \mathrm{il} ., \$ 9.75$.

EXTERNAL OTITIS: Diagnosis and Treatment $b y$ Edley H. Jones, Univ. of Mississippi, Jackson. (Ret.). Heretofore unpublished clinical investigations are presented including a particularly effective study on the prevention of "swimming pool ear". Clinical findings are correlated with pathology and well illustrated with photomicrographs. Basic principles of general and local therapy which apply to all forms of external otitis are fully discussed. ' 65,264 pp., 89 il. ( 26 in colour), Ig tables, $\$ 9.5^{\circ}$

RADIATION THERAPY IN THE MANAGEMENT OF GANCERS OF THE ORAL CAVITY AND OROPHARYNX by Gilbert $H$. Fletcher and William S. MacComb. With the collaboration of Alando J. Ballantyne. Physics section by Robert J. Shalek and Marilyn A. Stovall. All of the Univ. of Texas. '62, 408 pp., 346 il. (Amer. Lec. Radiation Therapy edited by Milton Friedman), $\$ I 6.5^{\circ}$
Cash with Order Outside U.S.A. and Canada

We Pay Postage and Guarantee Delivery

CANCER OF THE NASOPHARYNX: Its Natural History and Treatment $b y$ M. Lederman, Royal Marsden Hospital. '61, 128 pp., 109 il. (Amer. Lec. Radiation Therapy), $\$ 6.75$

THE HUMAN LARYNX by Mervin C. Myerson, Cedars of Lebanon Hosp., Los Angeles. ' 64,408 pp., I 9 I il., 17 tables, $\$ 14 \cdot 5^{\circ}$

\section{GLINICAL AUDIOMETRY} by Michel and Claudine Portmann, both of Bordeaux Univ. Translated by Sheila Wevers, London, England, and Bruce Proctor, Wayne State Univ., Detroit, Mich. '61, $3^{8} 4$ pp., 147 il., $\$ 12.00$

THE NOSE, PARANASAL SINUSES, AND EARS IN CHILDHOOD by Donald F. Proctor, The Johns Hopkins Univ., Baltimore. ' 63,200 pp. $\left(8 \frac{1}{2} \times\right.$ I I ), I 83 il. (Pediatric Surgical Monograph Series edited by Mark M. Ravitch), $\$ 12.5^{\circ}$

THE TONSILS AND ADENOIDS IN CHILDHOOD $b y$ Donald F. Proctor, ' 60,82 pp. $\left(8 \frac{1}{2} \times\right.$ I I $), 46$ il. (I full colour plate), (Pediatric Surgical Monograph Series), $\$ 7.5^{\circ}$

Send for our new I966 Catalog SPRINGFIELD - ILLINOIS • U.S.A.

Please mention The Journal of Laryngology and Otology when replying to advertisements 


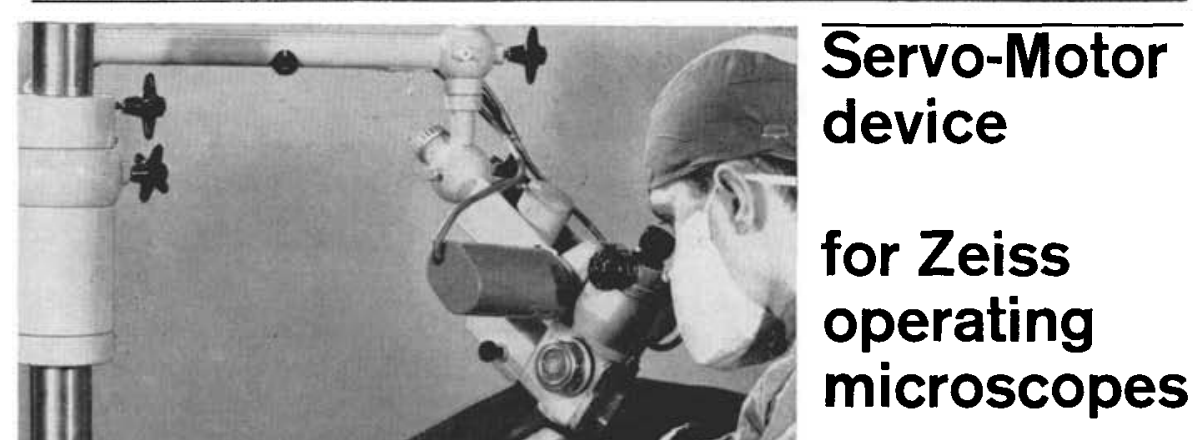

Simply by pressing a foot control the microscope can be focused either upwards or downwards leaving both hands free for manipulation purposes.

Full details

from sole suppliers

Degenhardt \& Co Ltd

Carl Zeiss House

20/22 Mortimer Street

London W1

Museum 8050 (15 lines)
Scottish enquiries to

Degenhardt \& Co

(Scotland) Ltd

22 Burnbank Gardens

Glasgow NW

Douglas 0520

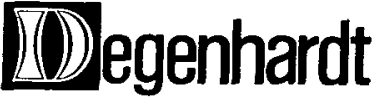

Please mention The Journal of Laryngology and Utology when replying to advertisements 


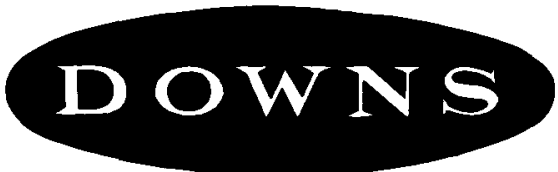

\section{OPERATING}

\section{CHAIR-STOOL}

HYDRAULIC, FOOT OPERATED

ADJUSTABLE HEIGHT 24 to $33 \mathrm{in.}$

ADJUSTABLE BACK REST

FOOT OPERATED BRAKE

FOOT RAIL

MAXIMUM MANEUVERABILITY

CAN BE ELEVATED AND LOCKED BY SURGEON WHILST SEATED

THIS CHAIR-STOOL IS OF SPECIAL VALUE IN PROLONGED OPERATIONS SUCH AS STAPEDECTOMY AND OPHTHALMIC SURGERY

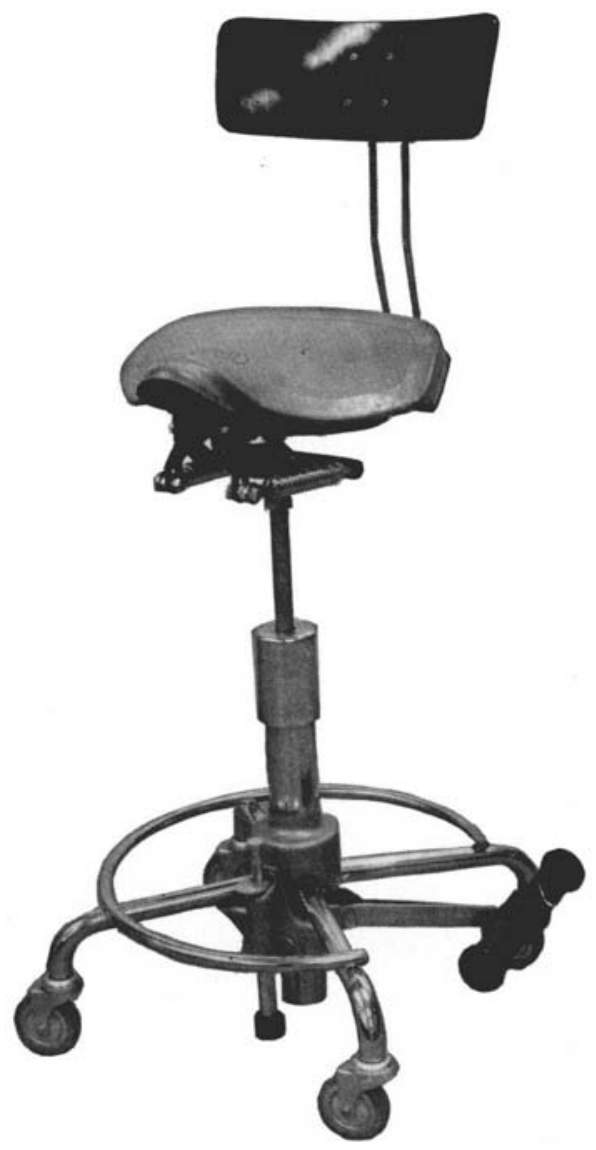

DOWN BROS. AND MAYER \& PHELPS LTD CHURCH PATH, MITCHAM, SURREY, ENGLAND In Canada

410 Dundas Street West, Toronto, 2B, Canada 


\section{'Otosporin' for ears and ears and ears..}

'Otosporin' drops rapidly destroy virtually all organisms commonly found in infections of the ear, reduce irritation, inflammation and pain.

\section{'Otosporin' ${ }_{\text {brand }}$ Drops}

contain polymyxin B sulphate, neomycin sulphate and hydrocortisone. Issued in bottles of $5 \mathrm{ml}$.

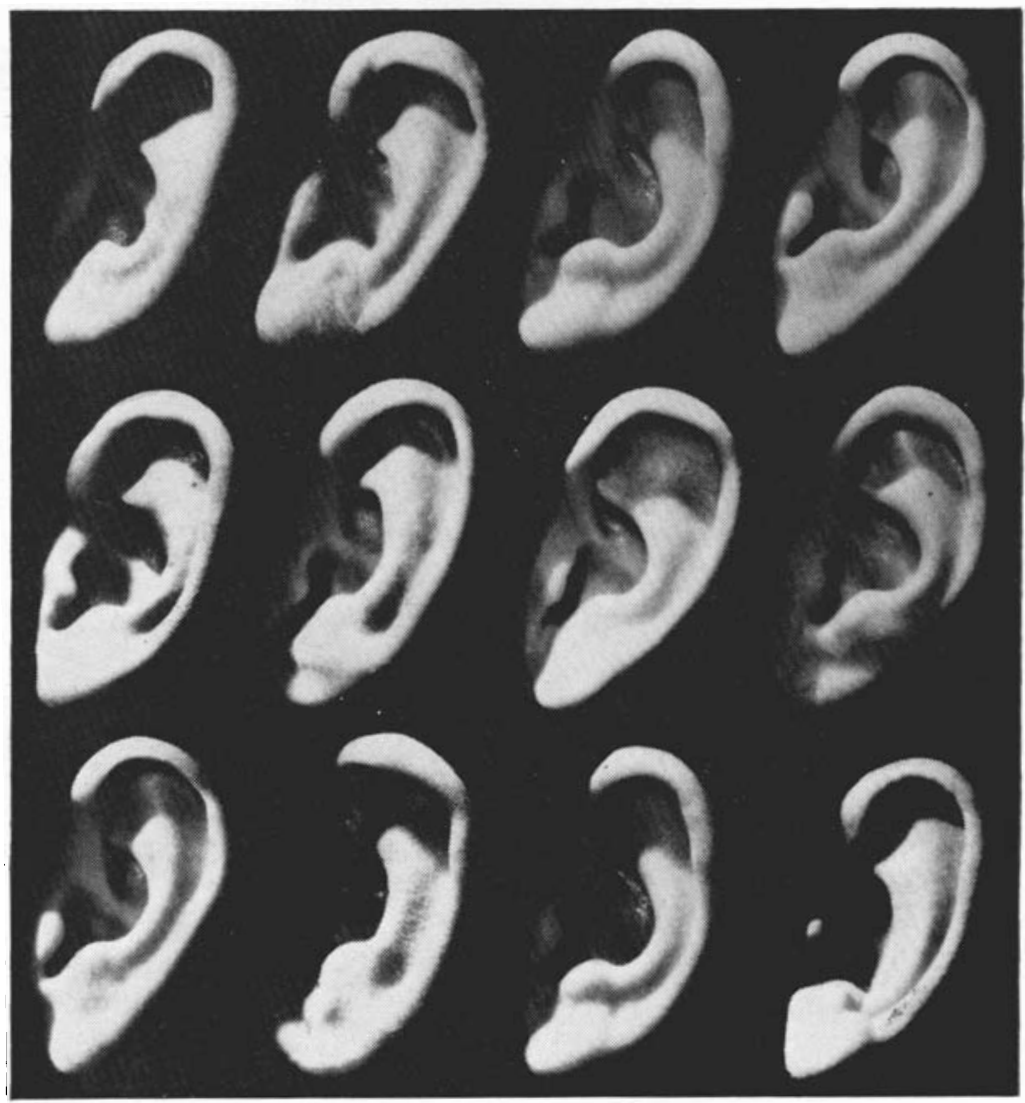

\section{ro}

Burroughs Wellcome \& Co. (The Wellcome Foundation Ltd.) London 